\title{
Bahasa Amiyah Mesir (Sejarah, Kaidah, dan Perbedaanya dengan Bahasa Arab Klasik)
}

\author{
Afridesy Puji Pancarani ${ }^{1}$, Zaqiatul Mardiah ${ }^{2}$, Ariadna Ayu Miranda ${ }^{3}$ \\ Program Studi Sastra Arab, Fakultas Sastra, Universitas Al Azhar Indonesia, Jalan Sisingamangaraja, \\ Kebayoran Baru, Jakarta Selatan, 12110
}

Penulis untuk Korespondensi/E-mail: afridesy@uai.ac.id

\begin{abstract}
Abstrak - Penelitian ini mengupas sejarah dan asal-usul bahasa Arab Amiyah Mesir yang juga menelusuri negara-negara mana saja yang bahasanya diserap oleh bahasa Amiyah Mesir. Teori yang digunakan penulis sebagai rujukan utama dalam menelaah kaidah bahasa Amiyah Mesir adalah teori Ahmad Akram Malibary yang kemudian membandingkannya dengan bahasa Arab Klasik. Dari perbandingan tersebut terlihat cukup signifikan perbedaannya antara kedua bahasa tersebut, baik dari sisi pengucapan hurufnya, maupun penambahan huruf akhir pada verba tertentu.
\end{abstract}

Kata kunci - Bahasa Amiyah Mesir, Bahasa Arab Klasik, Ahmad Akram Malibary

Abstract - This research examines the hisory and origins of Arabic language "Amiyah Mesir" wich also explores wich country absorbed by the "Amiyah Mesir "Language. The theory used the author as the main reference in examining the rues of "Amiyah Mesir" adalah Ahmad Akram Malibary's theory which then compares it with Clasical Arabic. From the comparison it looks quite significnt difference between the two languages, both in terms of pronounciations of the letters, as well as the addition of the final letter on a particular verb.

Keywords - Amiyah Mesir Language, Arab Clasical Language, Ahmad Akram Malibary

\section{PENDAHULUAN}

\section{Latar Pokok Bahasan}

$\mathrm{B}$ ahasa Arab merupakan bahasa mayor yang digunakan oleh lebih dari 200.000.000 penduduk. Bahasa Arab dijadikan sebagai bahasa resmi di negara arab sebanyak kurang lebih 20 negara. Bahasa yang awalnya berasal dari rumpun basaha-bahasa Semit (Semitic Language/Samiyah) ini mempunyai anggota penutur terbanyak. Di semenanjung arabia misalnya, bahasa ini menjadi bahasa administrasi dan politik, diantaranya adalah Yaman, Saudi Arabia, Bahrain, Kuwait, Mesir dan beberapa negara lainnya. Begitu juga di Afrika, bahasa ini merupakan bahasa pertama dan populer di negara Maroko, Aljazair, Libya, dan MaurItania.

Jika kita melirik lebih dalam bahasa yang digunakan di Mesir, sebenarnya tidak jauh berbeda dengan bahasa Indonesia yang sangat kaya akan bahasa di tiap-tiap daerahnya. Di Mesir, tidak saja bahasa Arab klasik yang mereka gunakan untuk komunikasi sehari-hari, melainkan ia memiliki banyak bahasa sesuai dengan daerah dan lingkungannya. Ada yang dinamakan bahasa Misr Sha'idy, yaitu bahasa yang digunakan oleh penduduk sebelah utara Mesir. Tidak jarang penduduk yang bukan berasal dari bagian utara ini memahami bahasa Misr Sha'idy. Karena bahasa ini memiliki ciri 
khusus yang hanya difahami oleh warganya. Diantara kekhususannya adalah, mereka memiliki simbol-simbol khusus dalam berkomunikasi.

Ada lagi yang dinamakan bahasa Misr Iskandarany. Bahasa ini jelas merupakan bahasa yang digunakan oleh penduduk Iskandaria (Alexandria) dan sekitarnya. Ada pula yang dinamakan bahasa Nuwaebah, yaitu bahasa yang digunakan oleh penduduk Luxor dan Aswan yang terletak tepat diujung negara Mesir yang menjadi pembatas antara Mesir dan Sudan. Selain bahasa, daerah ini juga memiliki warna kulit yang berbeda dengan orang-orang Mesir pada umumnya. Mereka berkulit hitam, karena cuaca di kota ini pun hampir bahkan sama dengan suhu di negara Sudan yang merupakan daerah yang terkenal sangat panas. Selain bahasa-bahasa di atas, diantara bahasa yang sangat populer dan menonjol di Mesir adalah bahasa bahasa Al-Araby Al Misry atau Amiyah Mesir. Bahasa inilah yang sangat terkenal dan populer di kalangan penduduk Mesir bahkan sampai ke negara-negara semenanjung arab.

Di Maroko misalnya, sekalipun Maroko mempunyai bahasa komunikasi sendiri, tapi ketika seseorang berbicara dengan penduduk Maroko menggunakan bahasa Amiyah Mesir, dengan mudahnya ia memahami, bahkan ia mampu berkomunikasi dengan bahasa Amiyah Mesir itu. Mereka menganggap bahasa Amiyah Mesir merupakan bahasa yang sangat 'familiar' didengar.

Adapun beberapa perbedaan dalam melafalkan bahasa Arab formal dan bahasa Amiyah Mesir diantaranya sebagai berikut:

Tabel 1. Perbedaan dalam melafalkan bahasa Arab formal dan bahasa Amiyah Mesir

\begin{tabular}{cc}
\hline Bahasa Arab Klasik & Bahasa Amiyah Mesir \\
\hline$ق$ & 1 \\
\hline$ج$ & $\dot{\varepsilon}$ \\
\hline$s$ & $ي$ \\
\hline
\end{tabular}

Yang menyebabkan perbedaan-perbedaan kata di atas, adalah karena bahasa Amiyah Mesir diserap dari beberapa negara, seperti: Turki, Italia, Perancis, Yunani, dan Inggris.

\section{Rumusan Masalah}

Berdasarkan uraian pada sub-bab sebelumnya, rumusan masalah dari penelitian adalah sebagai berikut:

1. Bahasa apa saja yang menjadi sumber serapan bahasa Amiyah Mesir?

2. Apakah perbedaan bahasa Arab Formal dengan bahasa Amiyah Mesir dari segi kaidah (rumus-rumus)?

3. Adakah gramatika khusus yang dimiliki oleh bahasa Amiyah Mesir?

\section{Tujuan Penelitian}

Sesuai dengan rumusan masalah yang telah dijelaskan di atas, maka pada penelitian ini, penulis akan menjawab pertanyaan-pertanyaan yang tertuang dalam rumusan masalah, yaitu:

1. Mengetahui bahasa apa saja yang menjadi sumber serapan bahasa Amiyah Mesir.

2. Menelaah perbedaan antara kaidah bahasa Arab Klasik dengan bahasa Amiyah Mesir.

3. Menyingkap gramatika khusus yang dimiliki bahasa Amiyah Mesir.

\section{KAJIAN PUSTAKA}

\section{Tinjauan Pustaka}

Pembahasan mengenai hubungan bahasa Arab formal dengan bahasa Amiyah Mesir sebenarnya cukup menarik bagi orang-orang yang pernah mendengar atau berkecimpung dalam bahasa Amiyah Mesir. Tidak sedikit juga buku-buku yang membahas sejarah munculnya bahasa Amiyah Mesir, sampai kaidah-kaidah yang digunakan dan perbedaannya dengan bahasa Arab formal.

Terdapat banyak artikel yang menguraikan tentang perbedaan cara baca huruf-huruf hijaiyah yang digunakan dalam komunikasi berbahasa Amiyah Mesir. Dengan berbagai model, para penulis menuangkan pengalaman sedalam pemahamannya tentang bahasa Amiyah Mesir. Pembahasan ini akan menjadi semakin menarik ketika dikorelasikan dengan bahasa Arab formal, sehingga para pembelajar bahasa Amiyah Mesir dengan mudah mengingat rumus-rumus (kaidah-kaidah) yang jelas.

Diantara para penulis yang terkenal dalam karyanya mengenai bahasa Amiyah Mesir 
adalah sebagai berikut: Mukhtar Umar (1992) dalam karyanya Tarikh al-Lughah al-Arabiyah fi Misr wa al-Maghrib wa al-Adna, Naffusah Zakaria (1964) dalam bukunya Tarikh alDa'wah Ila al-Amiyahwa Atsaruha fii Misr, Israel Ben-Zeev (2008) dalam bukunya Tarikh al-Lughah al-Samiya

Sementara buku-buku sejarah dan kaidah bahasa Amiyah Mesir ramai bermunculan, para pembelajar juga banyak yang menulis rumusrumus dasar pada artikel-artikel atau di blognya. Walaupun sederhana, namun tetap saja bagi para pemula sangat bermanfaat, setidaknya untuk memahami lebih dalam rumus dan susunan-susunan kalimat bahasa Amiyah Mesir.

Selanjutnya, semakin berkembangnya pembelajaran budaya Arab di Indonesia, akan semakin banyak juga yang mempelajari sejarah bahasa Amiyah Mesir. Dengan begitu sasaran pada penelitian ini akan semakin ramai dicari oleh para pembelajar.

Selain kaidah-kaidah Amiyah Mesir, banyak juga para pemerhati dan pecinta bahasa Arab Mesir yang menterjemahkan cerita-cerita, riwayat, novel ke dalam bahasa Indonesia atau bahasa Arab Formal dari bahasa Amiyah Mesir. Hal ini juga akan sangat membantu penulis dalam meneliti.

\section{Letak Geografis Mesir}

Bahasa Mesir merupakan bahasa ibu kurang lebih 76 juta penduduk mesir, ditambah para imigran yang menetap di Mesir, seperti: Timur Tengah, Eropa, Amerika Utara, Australia dan Asia Tenggara. Diantara penyebab berkembangnya bahasa Mesir di kancah internasional adalah:

a. Para delegasi Mesir yang dikirim ke berbagai negara dalam rangka penyebaran ilmu di Libia, Aljazair dan beberapa negara Asia.

b. Tersebarnya film-film Mesir dibeberapa negara Arab pada awal abad 20.

\section{Sejarah Munculnya Bahasa Mesir}

Bahasa Amiyah Mesir merupakan bahasa tertua yang masih digunakan oleh para penduduk semenanjung arab. Bahasa ini muncul dan sudah tertulis sekitar tahun 3400 SM. Para penduduk Mesir awalnya menggunakan bahasa
Koptik dalam kehidupan sehari-hari. Namun pada tahun $641 \mathrm{M}$, setelah perang negara Arab melawan Mesir, mulailah para penduduk arab membedakan bahasa mereka dengan bahasa Mesir. Abdul Malik bin Marwan Al-Umawy membuat peraturan, bahwa warga Mesir dilarang menggunakan bahasa Koptik dalam komunikasi mereka.

Kurang lebih 3 tahun setelah perang antara Mesir dan negara arab, terjadi percampuran bahasa antara bahasa Mesir dengan bahasa Koptik, khususnya di daerah-daerah terpencil. Hal ini terus terjadi sampai abad ke-17. Sampai akhirnya bahasa Amiyah Mesir benar-benar muncul dan diresmikan di sebuah pusat kota yang saat itu merupaka ibu kota Islam di Mesir, yaitu Fustat, saat itu bahasa Koptik dilarang untuk digunakan, sekalipun orang Nasrani.

\section{Bahasa Amiyah Mesir, Bahasa atau Dialek?}

Masih menjadi perdebatan dikalangan ahli bahasa, apakah bahasa yang digunakan komunikasi penduduk Mesir sehari-hari merupakan bahasa, atau hanya dialek?

Diantara pendapat para ahli bahasa dalam hal ini adalah:

1. Bahasa Amiyah Mesir adalah bahasa, bukan dialek karena memiliki kaidah dan rumus-rumus tertentu untuk memahaminya. Golongan ini memiliki beberapa alasan, diantaranya:

a. Walaupun kosakata bahasa Amiyah Mesir sedikit banyak berbeda dengan bahasa arab, akan tetapi lafadzh (kata) bukan merupakan alasan utama sebuah bahasa. Sama halnya bahasa Inggris. Lebih dari sepertiga bahasa Inggris merupakan serapan dari bahasa Perancis. Dan selebihnya bahasa Inggris diserap dari berbagai bahasa, misalnya: Jerman, Celtic, Latin, dan Scandinavian. Bahkan bisa dikatan tidak ada bahasa asli yang diambil dari Inggris. Namun, ia tetap dikatakan bahasa Inggris.

b. Kosakata itu bukan asas atau inti dari sebuah bahasa. Adapun yang merupakan inti dan ciri dari sebuah bahasa adalah gramatikalnya.

2. Bahasa Amiyah Mesir merupakan satu diantara sekian banyak dialek orang arab. Golongan ini memiliki alasan, yaitu 
bahasa Amiyah Mesir memiliki banyak kesamaan dengan bahasa arab, baik dari segi huruf maupun pelafalan kata.

Dari penjelasan di atas, akan terlihat korelasi bahasa Arab Klasik dengan bahasa Amiyah Mesir, dapat diibaratkan dengan kedekatan antara bahasa Inggris dengan bahasa Perancis. Yakni, kosakata-kosakata yang digunakan dalam bahasa Amiyah Mesir sebagaian diambil dari bahasa Arab Klasik. Namun, bukan berarti gramatikal bahasa Amiyah akan persis sama seperti bahasa Arab Klasik, karena bahasa Amiyah Mesir memiliki acuan gramatikal yang berbeda denga bahasa Arab Klasik.

\section{Bahasa yang Diserap oleh Bahasa Amiyah Mesir}

Bahasa Amiyah Mesir merupakan bahasa yang diserap dari beberapa negra tetangga, diantaranya:

\section{a. Italia}

Tabel 2. Bahasa Italia yang Diserap Bahasa Amiyah

\begin{tabular}{crrl}
\hline $\begin{array}{c}\text { Bahasa } \\
\text { Italia }\end{array}$ & $\begin{array}{c}\text { Bahasa } \\
\text { Arab } \\
\text { Klasik }\end{array}$ & $\begin{array}{c}\text { Bahasa } \\
\text { Amiyah } \\
\text { Mesir }\end{array}$ & $\begin{array}{c}\text { Bahasa } \\
\text { Indonesia }\end{array}$ \\
\hline Gamberi & Oمبري & Udang \\
\hline Vetrina & $\begin{array}{r}\text { Lemari } \\
\text { pajangan }\end{array}$ \\
& عرورينة & & \\
\hline
\end{tabular}

\section{b. Turki}

Tabel 3. Bahasa Turki yang Diserap Bahasa Amiyah

\begin{tabular}{crrl}
$\begin{array}{c}\text { Bahasa } \\
\text { Turki }\end{array}$ & $\begin{array}{c}\text { Bahasa } \\
\text { Arab } \\
\text { Klasik }\end{array}$ & $\begin{array}{c}\text { Bahasa } \\
\text { Amiyah } \\
\text { Mesir }\end{array}$ & $\begin{array}{c}\text { Bahasa } \\
\text { Indonesia }\end{array}$ \\
\hline Oda & غوفة & Kamar \\
Boya & غوية & Cat \\
\hline
\end{tabular}

\section{c. Persia}

Tabel 4. Bahasa Persia yang Diserap Bahsa Amiyah

\begin{tabular}{rrrl}
\hline $\begin{array}{c}\text { Bahasa } \\
\text { Persia }\end{array}$ & $\begin{array}{c}\text { Bahasa } \\
\text { Arab } \\
\text { Klasik }\end{array}$ & $\begin{array}{c}\text { Bahasa } \\
\text { Amiyah } \\
\text { Mesir }\end{array}$ & $\begin{array}{c}\text { Bahasa } \\
\text { Indonesia }\end{array}$ \\
\hline ترشي & ترشي & Asinan \\
\hline ترزي & Penjahit \\
\hline
\end{tabular}

\section{d. Perancis}

Tabel 5. Bahasa Perancis yang Diserap Bahasa Amiyah

\begin{tabular}{lrrl}
\hline \multicolumn{1}{c}{$\begin{array}{c}\text { Bahasa } \\
\text { Perancis }\end{array}$} & $\begin{array}{c}\text { Bahasa } \\
\text { Arab } \\
\text { Klasik }\end{array}$ & $\begin{array}{c}\text { Bahasa } \\
\text { Amiyah } \\
\text { Mesir }\end{array}$ & $\begin{array}{c}\text { Bahasa } \\
\text { Indonesia }\end{array}$ \\
\hline Êcharpe & إيشارب & Jilbab \\
\hline Direction & Marka \\
& & & jalan \\
\hline
\end{tabular}

\section{e. Yunani}

Tabel 6. Bahasa Yunani yang Diserap Bahasa Amiyah

\begin{tabular}{|c|c|c|c|}
\hline Bahasa Yunani & $\begin{array}{c}\text { Bahasa } \\
\text { Arab } \\
\text { Klasik }\end{array}$ & $\begin{array}{c}\text { Bahasa } \\
\text { Amiyah } \\
\text { Mesir }\end{array}$ & $\begin{array}{c}\text { Bahasa } \\
\text { Indonesia }\end{array}$ \\
\hline \multirow[t]{3}{*}{ 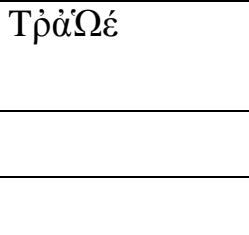 } & طاولة & ترابيزة & $\begin{array}{l}\text { Meja } \\
\text { makan }\end{array}$ \\
\hline & مصباح & فانوس & Lampu \\
\hline & توت أرضي & فراولة & Strawberi \\
\hline
\end{tabular}

\section{f. Inggris}

Tabel 7. Bahasa Inggris yang Diserap Bahasa Amiyah

\begin{tabular}{lrrl}
\hline Bahasa Inggris & $\begin{array}{c}\text { Bahasa } \\
\text { Arab } \\
\text { Klasik }\end{array}$ & $\begin{array}{c}\text { Bahasa } \\
\text { Amiyah } \\
\text { Mesir }\end{array}$ & $\begin{array}{c}\text { Bahasa } \\
\text { Indonesia }\end{array}$ \\
\hline Police & بوليس & Polisi \\
\hline Tramway & ترامواي & Kereta \\
\hline & كهربائية & listrik \\
\hline
\end{tabular}

\section{KERANGKA TEORI}

Kaidah bahasa Amiyah Mesir menurut Ahmad Akram Malibary

Sedangkan menurut Ahmad Akram Malibary dalam karyanya Al-Lughah Al-Amiyah AlMashriyah (Qawa'iduh -Ba'dhu Al-Kalimat wal Al-Asalib Al-Amiyah, Ba'dhu AlMuhadatsat Fii Mukhtalif Al-Maudhu'at), mengatakan bahwa terdapat lima belas teori umum bahasa Amiyah Mesir. Teori-teori tersebut adalah sebagai berikut: 


\section{Tidak memiliki harakat}

Bahasa Amiyah Mesir memang sejak awal terbentuk tanpa menggunakan harakat. Semua kalimat wajib disukunkan. Dan dalam konteks berbicara, menjadi sesuatu yang aneh jika seseorang tetap menggunakan harakat seperti layaknya berbicara bahasa Arba formal. Namun, akan ditemukan beberapa kalimat juga yang menuntut harus adanya harakat dalam pengucapan, satu diantaranya adalah untuk membedakan kata ganti kamu laki-laki dan perempuan, saya, dia laki-laki dan perempuan, yang memang pada dasarnya kata ganti yang satu dengan lainnya hanya dapt dibedakan dengan sebuah harakat. Dan tanpa adanya harakat, pernyataan atau ungkapan yang disampaikan oleh orang berbicara akan menimbulkan sebuah kerancuan karena tidak dapat membedakan siapa orang dimaksud dalam ungkapan atau kalimat tersebut.Contoh :

Tabel 8. Contoh Bahasa Amiyah Tidak Memiliki Harokat Sehingga Mengakibatkan Kerancuan.

\begin{tabular}{|c|c|c|}
\hline $\begin{array}{c}\text { Bahasa } \\
\text { Indonesia }\end{array}$ & $\begin{array}{c}\text { Bahasa } \\
\text { Arab } \\
\text { Formal }\end{array}$ & $\begin{array}{c}\text { Bahasa Amiyah } \\
\text { Mesir }\end{array}$ \\
\hline $\begin{array}{c}\text { Hari ini kita } \\
\text { memiliki tema } \\
\text { baru }\end{array}$ & هذ اليوم عندنا & 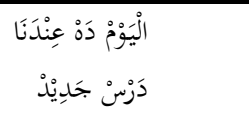 \\
\hline
\end{tabular}

\section{Terdapat penambahan huruf (ب) di awal}

\section{kata kerja}

Dalam bahasa Amiyah Mesir, penambahan huruf (ب) di awal kata kerja berfungsi untuk membedakan kata kerja yang memiliki makna sekarang (sedang berlangsung). Sementara kata kerja yang tidak mengalami penambahan huruf (ب) di awalnya memiliki makna yang akan datang (belum berlangsung).Contoh :

Tabel 9. Contoh Bahasa Amiyah dengan Penambahan Huruf (ب) di awal kata kerja

\begin{tabular}{|c|c|c|}
\hline $\begin{array}{c}\text { Bahasa } \\
\text { Indonesia }\end{array}$ & $\begin{array}{c}\text { Bahasa } \\
\text { Arab } \\
\text { Formal }\end{array}$ & $\begin{array}{c}\text { Bahasa } \\
\text { Amiyah } \\
\text { Mesir }\end{array}$ \\
\hline $\begin{array}{c}\text { Saya kira } \\
\text { sekarang } \\
\text { anda sudah } \\
\text { mulai } \\
\text { memahami }\end{array}$ & قليلا الآن & شوية دلوقت بتفهم أكتر \\
\hline
\end{tabular}

\section{Terdapat penambahan huruf $(\tau)$ pada awal} kata kerja

Sebagaimana terdapat penambahan huruf (ب) pada awal kata kerja yang mengandung makna sekarang (pekerjaan yang sedang berlangsung), penambahan huruf ( $($ )pada bahasa Amiyah Mesir memiliki makna akan berlangsung. Dan bisa dikatakan huruf $(\tau)$ ini menggantikan posisi huruf (سوف dan w pada bahasa Arab formal yang mengandung arti 'akan' (akan berlangsung). Contoh :

Tabel 10. Contoh Bahasa Amiyah dengan Penambahan Huruf ( $(\tau)$ di awal kata kerja

\begin{tabular}{|c|c|c|}
\hline $\begin{array}{l}\text { (ح)Bahasa } \\
\text { Indonesia }\end{array}$ & $\begin{array}{c}\text { Bahasa Arab } \\
\text { Formal }\end{array}$ & $\begin{array}{c}\text { Bahasa } \\
\text { Amiyah } \\
\text { Mesir }\end{array}$ \\
\hline $\begin{array}{c}\text { Disana kita } \\
\text { akan membeli } \\
\text { semuanya }\end{array}$ & هناك سوف نشتري & هناك حنشترى كل \\
\hline
\end{tabular}

\section{Penambahan huruf (ش) di akhir verba}

Verba lampau ataupun verba yang sedang berlangsung jika di awali dengan kata negatif (L) maka verba tersebut harus di akhiri dengan huruf (ش). Contoh :

Tabel 11. Contoh Bahasa Amiyah dengan Penambahan huruf (ش) di akhir verba.

\begin{tabular}{|c|c|c|}
\hline $\begin{array}{c}\text { Bahasa } \\
\text { Indonesia }\end{array}$ & $\begin{array}{c}\text { Bahasa } \\
\text { Arab } \\
\text { Formal }\end{array}$ & $\begin{array}{c}\text { Bahasa } \\
\text { Amiyah } \\
\text { Mesir }\end{array}$ \\
\hline $\begin{array}{c}\text { Kakak/adik } \\
\text { saya tidak } \\
\text { dating hari } \\
\text { ini }\end{array}$ & أخونا ما حضر & أخويا م حضرش \\
\hline
\end{tabular}

\section{Penambahan huruf (ش) yang bersanding dengan huruf (مالنافية)}

Cara menambah huruf (ش) ini adalah dengan menghapus huruf (I) yang terdapat pada huruf (Ь) dan mengganti harakat ( $($ ) menjadi dhommah. Dan akan menghasilkan huruf (مش). Ungakapan negatif ini menggantikan posisi huruf-huruf negatif pada bahasa Arab formal, seperti " Adapun penggunaan huruf (مش) itu selalu bersanding dengan nomina atau verba yang sedang berlangsung dan akan berlangsung. 
Contoh :

Tabel 12. Contoh Bahasa Amiyah Penambahan Huruf (ش) yang Bersanding dengan Huruf (شالنافية)

\begin{tabular}{ccc}
\hline & ) & \\
\hline Bahasa & Bahasa Arab & Bahasa \\
Indonesia & Formal & $\begin{array}{c}\text { Amiyah } \\
\text { Mesir }\end{array}$ \\
\hline $\begin{array}{c}\text { Kamu tidak } \\
\text { mengerti apa- } \\
\text { apa }\end{array}$ & & \\
\hline
\end{tabular}

\section{Huruf (ق) diucapkan dengan (s) atau (g)}

Huruf (ق) seperti yang seharusnya dilafalkan pada bahasa Arab klasik, sangat jarang terdengar di kalangan orang-orang Mesir. Mereka lebih familiar dan terbiasa melafalkannya dengan huruf 'hamzah' atau ' $g$ '. walaupun secara penulisan huruf-huruf tersebut tetap ditulis dengan huruf (ق).Contoh :

Tabel 12. Contoh Bahasa Amiyah dengan Huruf (ق)

\begin{tabular}{|c|c|c|}
\hline $\begin{array}{c}\text { Bahasa } \\
\text { Indonesia }\end{array}$ & $\begin{array}{c}\text { Bahasa } \\
\text { Arab } \\
\text { Formal } \\
\end{array}$ & $\begin{array}{c}\text { Bahasa } \\
\text { Amiyah } \\
\text { Mesir }\end{array}$ \\
\hline $\begin{array}{l}\text { Berdirilah } \\
\text { Hasan, dan } \\
\text { bacalah } \\
\text { bukumu! }\end{array}$ & قم يا حسن واقرأ & قوم يا حسن \\
\hline
\end{tabular}

\section{Huruf (ج) dilafalkan dengan huruf (j) atau} (g)

Contoh :

Tabel 13. Contoh Bahasa Amiyah dengan Huruf (ج) dilafalkan dengan huruf (j) atau (g)

\begin{tabular}{|c|c|c|}
\hline $\begin{array}{c}\text { Bahasa } \\
\text { Indonesia }\end{array}$ & $\begin{array}{c}\text { Bahasa Arab } \\
\text { Formal }\end{array}$ & $\begin{array}{c}\text { Bahasa } \\
\text { Amiyah } \\
\text { Mesir }\end{array}$ \\
\hline $\begin{array}{c}\text { Pulpen ini } \\
\text { bagus sekali }\end{array}$ & هذا القلم جمبل & لقلم دة جميل جدا \\
\hline
\end{tabular}

Huruf (ظ) lebih sering dilafalkan dengan huruf (ض)

Huruf (ظ) dalam bahasa Amiyah Mesir lebih sering dilaflkan dengan huruf (ض), walaupun sesekali masih ada yang melafalkan dengan huruf (ظ) yang semestinya, namun sangat jarang sekali terjadi.Contoh :
Tabel 14. Contoh Bahasa Amiyah dengan Huruf (ל) lebih sering dilafalkan dengan huruf (ض)

\begin{tabular}{lll}
\hline $\begin{array}{l}\text { Bahasa } \\
\text { Indonesia }\end{array}$ & $\begin{array}{l}\text { Bahasa Arab } \\
\text { Formal }\end{array}$ & $\begin{array}{l}\text { Bahasa } \\
\text { Amiyah } \\
\text { Mesir }\end{array}$ \\
\hline $\begin{array}{l}\text { Pakaian saya } \\
\text { hari ini bersih }\end{array}$ & & \\
\hline
\end{tabular}

\section{Huruf (ث) dibaca $(ت)$}

Secara umum, huruf $(\uplus)$ dalam bahasa Amiyah Mesir dibaca dengan huruf $(ت)$, walaupun sebagian kecil masih ada yang membacanya dengan huruf $(ث)$ seperti yang digunakan dalam bahasa Arab formal.Contoh :

Tabel 15. Contoh Bahasa Amiyah dengan Huruf Huruf $(\dot{*})$ dibaca $(ت)$

\begin{tabular}{|c|c|c|}
\hline $\begin{array}{c}\text { Bahasa } \\
\text { Indonesia }\end{array}$ & $\begin{array}{c}\text { Bahasa Arab } \\
\text { Formal }\end{array}$ & $\begin{array}{c}\text { Bahasa } \\
\text { Amiyah } \\
\text { Mesir }\end{array}$ \\
\hline $\begin{array}{c}\text { Usiaku } \\
\text { sekarang } 33 \\
\text { tahun }\end{array}$ & عمري الآن ثلاثة & عمري دلوقت تلات \\
\hline
\end{tabular}

\section{Perbedaan Kata Tanya}

Ada beberapa kata Tanya dalam bahasa Amiyah Mesir yang berbeda dengan bahasa Arab formal dalam pelafalannya. Contoh :

Tabel 16. Contoh Bahasa Amiyah dengan Perbedaan Kata Tanya

\begin{tabular}{ccc}
\hline $\begin{array}{c}\text { Bahasa } \\
\text { Indonesia }\end{array}$ & $\begin{array}{c}\text { Bahasa Arab } \\
\text { Formal }\end{array}$ & $\begin{array}{c}\text { Bahasa } \\
\text { Amiyah } \\
\text { Mesir }\end{array}$ \\
\hline $\begin{array}{c}\text { Siapa } \\
\text { namamu, Nak? }\end{array}$ & $؟$ اسمك إيمك يابن ابني \\
\hline
\end{tabular}

\section{Perbedaan Kata Tunjuk}

Terdapat beberapa perbedaan kata tunjuk dalam bahasa Arab formal dengan bahasa Amiyah Mesir.Contoh :

Tabel 17. Contoh Bahasa Amiyah dengan Perbedaan Kata Tunjuk

\begin{tabular}{|c|c|c|}
\hline \multicolumn{3}{|c|}{ Uadi Nata 1 u } \\
\hline Bahasa & Bahasa Arab & Bahasa \\
\hline Indonesia & Formal & $\begin{array}{l}\text { Amiyah } \\
\text { Mesir }\end{array}$ \\
\hline $\begin{array}{l}\text { Hamid, ambil } \\
\text { pulpen ini }\end{array}$ & يا حامد خذ هذا & يا حامد خذ لقلم دا \\
\hline
\end{tabular}




\section{ANALISIS}

\section{Biografi Amru Diab}

Adapun data-data yang penulis dapatkan terkait penyanyi lagu We Maloh adalah sebagai berikut :

Nama asli

: Amr Abd-Albaseet Abd-Azeez Diab

Nama tenar : Amr Diab

Tempat, tanggal lahir : Port Said Mesir, 11 Oktober 1961

Pekerjaan : Penyanyi, Komposer, Arranger, Aktor Instrumen Vokal, Gitaris Ayahnya : Ayahnya adalah seorang Kelautan Konstruksi dan Shipbuilding. Ayahnya lah yang menjadi salah satu inspirator Amr Diab untuk menjadi seorang penyanyi profesional.

Album : Diantara albumalbumnya adalah Tamally Ma'ak (2000), Ahla W Ahla (2016), El-Leila (2013), Leily Nahary (2004), Shoft El Ayam (2014), El-Lilady (2007), Matkhafeesh (1990), Banadeek Ta'ala (2011)

Perjalanan karir : Perjalanan karir Amr Diab benar-benar bergantung kepada pekerjaannya sebagai penyanyi. Karena dari menyanyi lah ia bisa berhasil mengharumkan namanya di dunia Timur Tengah. Pada usia enam tahun, Amr Diab pernah bernyanyi di Festival Juli 23 di Port Said. Karena keindahan suaranya tidak disangka-sangka ia mendapatkan penghargaan yang luar biasa dengan mendapatkan gitar dari gubernur Port Said kala itu.

Tahun 1983 ia merilis album studio pertamanya yang berjudul ' $Y a$ Tareeq'. Dan antara tahun 1984 dan 1987 ia merilis tiga album lebih yang meraih kesuksesan di dunia musik Timur Tengah kala itu.

Ia dikenal sebagai bapak musik Mediterania. Karena mampu menciptakan lagu dengan gayanya sendiri yang sering disebut 'Musik Mediterania' atau 'Sound Mediterania' yang merupakan perpaduan antara Barat dan Mesir. Sampai-sampai lagunya diterjemahkan ke dalam tujuh bahasa yang berbeda dan kemudian dinyanyikan oleh seniman dari berbagai negara di seluruh dunia. Pada tahun 1992 ia dinobatkan sebagai artis Arab pertama yang memulai membuat teknologi tinggi video musik 'Habibi'. Pada tahun 1996 album Nour
El Ain menjadi hit di seluruh dunia dan remix oleh banyak top dunia DJ pada saat itu.

Pengaruh dan kontribusi Diab merevolusi bisnis pertunjukan Mesir dalam beberapa hal, dan beberapa penulis telah menyebtnya sebagai pemberontak karena dia menantang segala sesuatu dalam bisnis pertunujukan Timur Trngah, dari gaya rambut dan penampilan gaya musik, presentasi, dan skala keuangan dari proyek-proyeknya.

Pada tahun 1997 ia memenangkan tiga penghargaan di Festival Arab Tahunan, yaitu: Video Terbaik, Best Song dan Artis Terbaik. Dan tahun berikutnya ia menerima Platinum Award untuk penjualan triple Nour El Ain dan juga penghargaan World Music di Monaco.

Menurut Mari kita Go Mesir, ia merupakan artis terlaris Mesir sepanjang masa. Sesuai yang dilansir pada kheelmeet.blogspot.co.id, ia dianugerahi Penghargaan Musik Dunia untuk penjualan terbaik di Timur Tengah sebanyak empat kali, yaitu pada tahun 1998, 2002, 2007 dan 2009. Ia juga mampu menjual lebih dari 50 juta di seluruh dunia. Sampai akhirnya ia dianggap sebagai penyanyi top di dunia Arab dan penyanyi legendaris oleh banyak penggemarnya di dunia Arab.

Lagunya yang cukup terkenal di Indonesia adalah Habibi ya Nur El Ain. Yang kerap kali dinyanyikan pada saat hajatan dengan alunan musik gambus. Sampai saat ini ia telah berhasil merilis 16 album yang meledak di pasaran dan menjadikannya dikenal sebagai Supestar Dunia Arab.

\section{Analisis Lagu}

\section{Lirik Lagu}

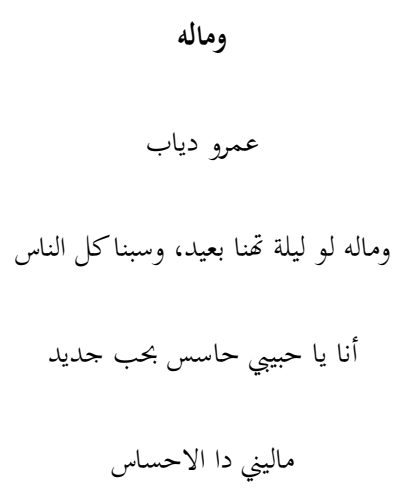




$$
\begin{aligned}
& \text { وانا هنا جنبي أغلى الناس } \\
& \text { انا جنبي احلى الناس } \\
& \text { حبيى ليلة تعالى ننسى فيها اللى راح } \\
& \text { تعالى جوا حضنى وارتاح } \\
& \text { دى ليلة تسوى كل الحياه } \\
& \text { ومالى غيرك ولولا حبك هعيش لمين } \\
& \text { حبيبى جاية اجمل سنين } \\
& \text { وكل مادة تحلى الحياه } \\
& \text { حببي المس ايديا عشان اصدق اللى أنا فيه } \\
& \text { ياما كان نفسى اقابلك بقالى زمان، خلاص وهحلم ليه } \\
& \text { مانا هنا جنبي أغلى الناس، جنبي احلى الناس } \\
& \text { حبيبى ليله } \\
& \text { تعالى ننسى فيها اللى راح } \\
& \text { تعالى جوا حضنى وارتاح } \\
& \text { دى ليلة تسوى كل الحياه } \\
& \text { ومالى غيرك ولولا حبك هعيش لمين } \\
& \text { حبيبى جاية اجمل سنين } \\
& \text { وكل مادة تحلى الحياه }
\end{aligned}
$$

\section{Analisis Data}

Dalam lagu ini, penulis membagi data sesuai dengan baris atau lirik lagu yang kemudian penulis rinci dan jelaskan satu persatu sesuai dengan teori yang digunakan.

\section{Data I}

Teks dalam bahasa Amiyah Mesir :

$$
\text { وماله لو ليلة تهنا بعيد }
$$

\section{We malo law leila tohna baeed}

Terjemahan ke dalam bahasa Arab Klasik :

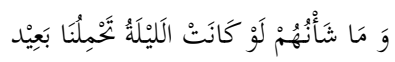

Dan apa urusan mereka jika malam ini membawa kita ke tempat yang jauh

\section{Keterangan :}

Kata o berasal dari dua kata, yaitu yang bermakna apa urusan mereka. Kata-kata seperti jarang sekali digunakan dalam komunikasi berbahasa Arab klasik. Namun kata ini sangat sering digunakan dalam bahasa Amiyah Mesir. Sementara dalam bahasa Arab klasik yang pupoler digunakan adalah ماشأقم . jika dilihat dari segi pelafalan, jelas bahasa Amiyah Mesir jauh lebih mudah dan cukup simpel diucapkan.

\section{Data 2}

Teks dalam bahasa Amiyah Mesir :

$$
\text { وسبنا كل الناس }
$$

\section{We sebna Kol el nas}

Terjemahan ke dalam bahasa Arab Klasik :

$$
\text { وَتركنا كُلَ النَّاسِ }
$$

Dan kita meninggalkan semua orang

\section{Keterangan :}

Pada lirik di atas terdapat kata سبنا yang bermakna تركنا. Kata سبنا sebenarnya berasal dari bahasa Arab klasik (سركاب - يسيب), namun dalam kehidupan sehari-hari kata ini sangat jarang sekali didengar. Sehingga banyak orang baik asing maupun warga negara sekalipun yang tidak mengetahui, bahwa kata tersebut adalah bahasa Arab klasik dan mereka semata-mata menganggap kata tersebut adalah bahasa Amiyah Mesir yang lebih mudah dan simpel diulafalkan daripada bahasa Arab klasik.

\section{Data 3}

Teks dalam bahasa Amiyah Mesir :

$$
\text { أنا يا حبيبي حاسس بحب جديد }
$$

Ana, ya habibi, hassis bi hob gideed

Terjemahan ke dalam bahasa Arab Klasik :

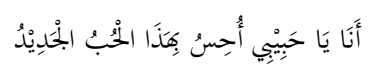

Sayangku, kini aku merasakan perasaaan jatuh cinta yang baru 


\section{Keterangan :}

Lirik di atas menggunakan kata حاسس sebagai pengganti kata أحس. Sebenarnya keduanya sama-sama berasal dari bahasa Arab Klasik, namun dalam kaidah bahasa Arab yang benar, pada konteks di atas yang benar adalah menggunakan fi'il mudhari bukan ism fa'il. Akan tetapi dalam penggunaan bahasa Amiyah Mesir sehari-hari, memang penggunaan fi'il mudhari termasuk jarang digunakan, karena penutur lebih senang dan simple menggunakan bentuk ism fa'il, dan hal ini bukan hal yang asing dalam bahasa Amiyah Mesir.

\section{Data 4}

Teks dalam bahasa Amiyah Mesir :

$$
\text { ماليني دا الاحساس }
$$

Malini dah el ehsas

Terjemahan ke dalam bahasa Arab Klasik :

$$
\text { مَلَئَتْنِنِ هَذَا الْإِحْسَاس }
$$

Engkau telah menyempurnakan perasaan ini

\section{Keterangan :}

Kata ماليني pada lirik di atas berasal dari kata

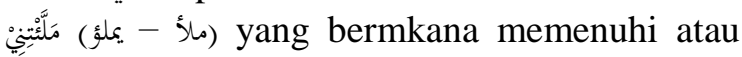
menyempurnakan. Namun, fonem $\&$ dalam bahasa Amiyah Mesir akan berubah menjadi pada saat dilafalkan. Maka dari itu dalam komunikasi berbhasa Amiyah Mesir, kita tidak akan pernah mendengar fonem $\&$ yang memang berasal dari \&. Adapun fonem \& akan kita dengar jika mengucapkan kata yang asal ق fonemnya adalah huruf ق dalam bahasa Amiyah Mesir akan berubah menjadi $\&$ dalam pelafalan .

Dan kata I pada lirik di atas merupakan perubahan dari kata penunjuk هذ. yang memiliki makna ini untuk maskulin. Dalam bahasa Amiyah Mesir hampir kata penunjuk yang klasik tidak pernah didengar.

\section{Data 5}

Teks dalam bahasa Amiyah Mesir :

$$
\text { وانا هنا جنبي أغلى الناس }
$$

Wa ana hena ganbi agla el nas
Terjemahan ke dalam bahasa Arab Klasik :

$$
\text { وَأَنَا هُئَا بِجَانِبِ أَغْلَى النَاسِ }
$$

Dan aku akan selalu di sini berada di samping wanita temahal (terhebat)

\section{Keterangan :}

Kata keterangan tempat هُ dalam bahasa Arab klasik adalah هُ. Memang terlihat sepele perbedaanya, karena hanya berbeda harakat antara dhommah dan kasrah. Namun hakikatnya keterangan tempat dalam bahasa Arab klasik ini hampir tidak pernah digunakan oleh penutur dalam percakapan berbahasa Amiyah Mesir.

Fonem جن جنب dalam bahasa Amiyah Mesir dilafalkan dengan huruf ' $\mathrm{g}$ '. Hal ini sudah menjadi umum di kalanga masyarakat Mesir. Bahkan tidak sedikit mereka yang tidak dapat melafalkan huruf ج. Hal ini terlihat jelas ketika mereka membaca kitab suci Al-Quran. Dimana huruf-huruf ج mereka baca dengan huruf ' $g$ '.

\section{Data 6}

Teks dalam bahasa Amiyah Mesir :

$$
\text { جنبي احلى الناس }
$$

Ana ganbi ahla el nas

Terjemahan ke dalam Bahasa Arab klasik :

$$
\begin{aligned}
& \text { Dِحَانِبِ أَحْلَى النَّاسِ } \\
& \text { Di samping wanita tercantik }
\end{aligned}
$$

Keterangan :

Huruf جنبي dadam lirik di atas dibaca dengan huruf ' $g$ ' yang seharusnya dibaca dengan huruf ' $\mathrm{j}$ ' dalam bahasa Arab klasik. Kemudian dapat kita perhatikan, bahwa katakata dalam bahasa Amiyah Mesir tidak pernah memperhatikan penggunaan hamzah, yang mana ada tidaknya hamzah dalam bahasa Arab klasik memiliki makna yang berbeda-beda.

\section{Data 7}

Teks dalam bahasa Amiyah Mesir :

$$
\text { حببيى ليله تعالى ننسى فيها اللى راح }
$$

Habibi, leilah taala ninsa feeha elli rah 
Terjemahan ke dalam bahasa Arab Klasik :

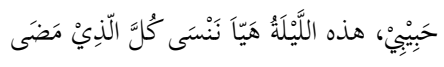

Sayangku, malam ini, marilah kita lupakan semua yang telah berlalu

Keterangan :

Pada lirik di atas dapat kita fahami, bahwa dalam bahasa Amiyah Mesir tidak semua kata tunjuk harus ditulis dan diucapkan pada sebuah kalimat, walaupun hakikatnya makna dari kalimat tersebut mengandung kata tunjuk di dalamnya. Kemudian pada kata نسى dalam bahasa Arab klasik dibaca dengan menggunakan harakat fathah pada huruf ن pertama, namun pada bahasa Amiyah Mesir huruf tersebut dibaca dengan harakat kasrah. Hal ini menunjukkan bahwa bahasa Amiyah Mesir sangat tidak memperhatikan kaidah yang benar walaupun hanya untuk satu huruf saja.selanjutnya kata sambung الّذنين dalam bahasa Amiyah Mesir dapat kita lihat perubahannya yang cukup signifikan, yaitu berubah menjadi اللى dan tidak memperhatikan gender dan nominalnya.

\section{Data 8}

Teks dalam bahasa Amiyah Mesir :

$$
\text { تعالى جوة حضنى وارتاح }
$$

Taala gowwa hodni wa irtah

Terjemahan ke dalam bahasa Arab Formal :

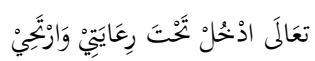

Ayolah masuk ke dalam pelukanku dan nikmatilah

Keterangan :

Kata جوة yang bermakna 'dalam' lebih familiar digunakan oleh penutur Amiyah Mesir daripada kata إد, dan pelafalan huruf ج juga diganti dengan huruf ' $g$ '. Hal ini menunjukkan bahwa huruf $ج$ lebih sering dilafalkan dengan huruf 'g' pada bahasa Amiyah Mesir. Kemudian pada kata ارتاح yang bermakna 'nikmatilah', tidak digunakan sesuai dengan kaidah bahasa Arab klasik yang berlaku. Karena untuk kata perintah, dalam bahasa Arab klasik memiliki rumus dan aturan yang baku. Adapun kata perintah dalam bahasa Arab klasik pada

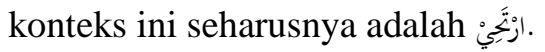

\section{Data 9}

Teks dalam bahasa Amiyah Mesir :

$$
\text { دى ليلة تسوى كل الحياه }
$$

Di leilah tiswa kol el hayah

Terjemahan ke dalam bahasa Arab Klasik :

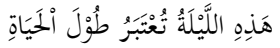

$$
\begin{aligned}
& \text { Malam ini sangat berarti sepanjang } \\
& \text { masa }
\end{aligned}
$$

Keterangan :

Pada lirik di atas terdapat dua kata yang menjadi konsentrasi dalam penelitian. Yaitu kata s yang merupakan kata tunjuk femina, sesuai dengan rumus yang berlaku, asal kata tersebut dalam bahasa Arab klasik adalah هَذِِ . kemudian kata تسوى yang digunakan pada lirik di atas, sebenarnya bukan hal baku yang pasti digunakan dalam bahasa Amiyah Mesir untuk menggantikan kata تُعْبَرُ namun hal ini bolehboleh saja.

\section{Data 10}

Teks dalam bahasa Amiyah Mesir :

$$
\text { ومالى غيرك ولولا حبك هعيش لمين }
$$

We Mali gheirak we lola hobbak ha'esh le meen

Terjemahan ke dalam bahasa Arab Klasik :

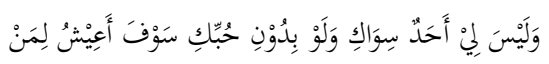

Aku tidak punya siapa-siapa, dan jika tanpa cintamu, untuk siapa aku hidup?

Keterangan :

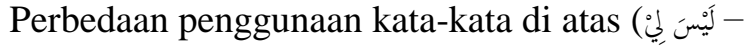

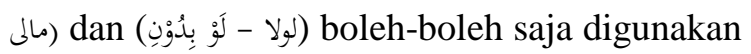
dalam dua bahasa tersebut, (baik dalam bahasa Arab klasik, maupun Amiyah Mesir). Karena keduanya dibolehkan dalam kaidah bahasa Arab klasik. Adapun kata هes, huruf ه bermakna 'akan' dalam bahasa Amiyah Mesir, maka dalam bahasa Arab klasik diartikan أَعِيْشُ 


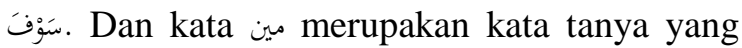
dalam bahasa Arab klasik adalah مَ.

\section{Data 11}

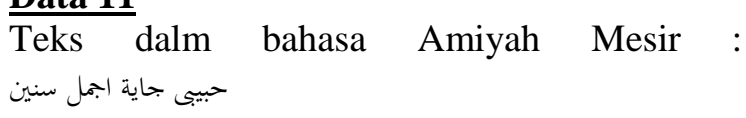

\section{Habibi gayya agmal sineen}

Terjemahan ke dalam bahasa Arab Klasik :

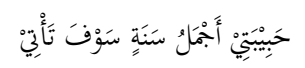

Keterangan :

Sayangku, tahun terbaik akan datang

Pada lirik di atas menunjukkan bahwa kata yang bermakna 'tahun' yang berbentuk tunggal, akan berubah dalam bahasa Amiyah Mesir menjadi سنين dalam bentuk jamak, apapun kondisinya.

\section{Data 12}

Teks dalam bahasa Amiyah Mesir :

$$
\text { وكل مادة تحلى الحياة }
$$

We kol madah tihla el haya

Terjemahan ke dalam bahasa Arab Klasik :

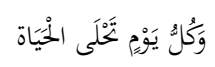

Dan hari-hari yang akan datang akan menjadi lebih baik

Keterangan :

Kata مادة yang digunakan lirik di atas dalam bahasa Amiyah Mesir, dapat diterjemahkan dalam bahasa Arab Klasik. Walaupun perbedaan kata tersebut tidak baku, namun pada beberapa konteks pilihan padanan kata tersebut dapat dijadikan solusi dalam menterjemahkan kata tersebut.

\section{Data 13}

Teks dalam bahasa Amiyah Mesir :

$$
\text { حبيب المس ايديا عشان اصدق اللى أنا فيه }
$$

Habibi ilmis eidayya, ashan asadda' elli ana feeh

Terjemahan ke dalam bahasa Arab Klasik :

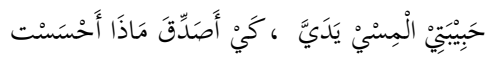

Sayangku, peganglah tanganku, agar aku bisa yakin dengan apa yang sedang aku rasa

Keterangan :

Pada kata المس, walaupun kata perintah tersebut ditujukan untuk femina, namun pada lirik di atas, tidak memperhatikan perbedaan gender. Maka dapat terlihat jelas, bahwa dalam hal ini, bahasa Amiyah Mesir keluar dari kaidah baku bahasa Arab klasik yang mempehatikan perbedaan gender pada kata perintah. Dan dalam konteks ini, bahasa Arab klasik yang tepat adalah الْمِسْيْ.

Begitu juga pada kata عشان yang merupakan

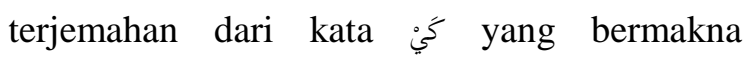
'agar/supaya'. Penggunaan kata عشان memang sangat sering dan dominan digunakan oleh masyarakat Mesir untuk menggantikan makna كَ.

\section{Data 14}

Teks dalam bahasa Amiyah Mesir :

$$
\text { ياما كان نفسى اقابلك بقالى زمان }
$$

Ya maa kan nifsi uqabilak ba'alli zaman

Terjemahan ke dalam bahasa Arab Klasik :

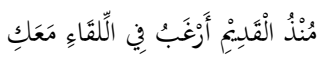

$$
\begin{aligned}
& \text { Sejak lama aku berharap bertemu } \\
& \text { denganmu }
\end{aligned}
$$

Keterangan :

Pada lirik di atas, dapat kita lihat adanya perubahan struktur antara bahasa Amiyah Mesir dengan bahasa Arab klasik. Hal ini bukan sesuatu yang baku, namun mungkin saja terjadi, bergantung kepada kebiasaan si penutur Mesir dalam mengungkapkan sesuatu. 
Adapun kata بقالى زمان dapat diterjemahkan ke dalam bahasa Arab klasik dengan kata زمنُْ الْنَدِيْ yang bermakna 'sejak lama'.

\section{Data 15}

Teks dalm bahasa Amiyah Mesir :

$$
\text { خلاص وهحلم ليه }
$$

\section{Khalas wa hahlam leih?}

Terjemahan ke dalam bahasa Arab Klasik :

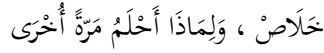

Sudahlah, untuk apa aku bermimpi

$$
\text { lagi? }
$$

Keterangan :

Dapat terlihat jelas perbedaan dua bahasa di atas, bahwa kata tanyaloِ yang merupakan bagian kata tanya dari bahasa Arab klasik, dalam bahasa Amiyah Mesir akan berubah menjadi لي hal ini terjadi dalam kondisi apapun dan seolah sudah menjadi rumus baku dalam bahasa Amiyah Mesir, sesuai dengan rumus bahasa Amiyah Mesir yang sudah penulis pada bab sebelumnya.

\section{KESIMPULAN DAN SARAN}

\section{Kesimpulan}

Berdasarkan hasil pencarian data baik melalui buku-buku, maupun pendapat para penutur Amiyah Mesir, penulis menyimpulkan beberapa hal, yaitu :

1. Bahasa Amiyah Mesir muncul tidak hanya disebabkan oleh faktor keanekaragaman daerah saja, melainkan karena bercampurnya warga negara asing, baik di negara Mesir itu sendiri, maupun di negara lain.
2. Bahasa Mesir menyerap bukan hanya dari negara yang menjajahnya saja, melainkan negara-negara tetangga lainnya juga mempengaruhi bahasa sehari-hari di Mesir, diantara negara-negara tersebut adalah : Italia, Turki, Persia, Perancis, Yunani, dan Inggris. 3. Perbedaan bahasa Amiyah Mesir dengan bahasa Arab klasik tidak hanya terletak pada tata bahasanya saja, melainkan terletak juga dari segi pelafalan huruf.

\section{Saran}

Penelitian ini akan menjadi lebih sempurna jika penulis lebih banyak mendapatkan referensireferensi yang khusus membahas tentang kaidah bahasa Amiyah Mesir. Di samping itu akan menjadi lebih ideal jika banyak penutur asli Mesir yang dijadikan responden dalam penelitian ini, sehingga kemungkinankemungkinan terjadi perbedaan antara kaidah yang ada dengan praktek komunikasi langsung di lapangan akan lebih terlihat dan dapat dijadikan pembahasan khusus pada teori ini.

\section{DAFTAR PUSTAKA}

(1) Hay'ah al-Misriyah al- 'Ammah lil Kitab (1991), al-Masra, University of Minnesota.

(2) Israel Ben-Zeev (1929), Tarikh alLughat al-Samiya, Maba'at al-I'timad bishari' Asan al-Akbar, University of California.

$$
\begin{aligned}
& \text { (3) دار مطبع محمدي (1959)، تاريخ الدعوة إلى العامية }
\end{aligned}
$$

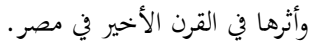

$$
\begin{aligned}
& \text { (4) قاموس المجة العامية المصرية _عربي-إبخليزي- (1999)، لئرن } \\
& \text { مكتبة لبنان. } \\
& \text { (5) مقدمة كتاب تحفة الوقاية في اللغة العامية المصرية } \\
& \text { (1980)، مطبعة شركة التمدن الصناعية. }
\end{aligned}
$$

